\title{
Experimental analysis of an improved cascade solar desalination still with modified absorber plate
}

\author{
Nidal Mouhsin ${ }^{*}$, Mariam Bouzaid ${ }^{1}$, and Mourad Taha-Janan ${ }^{1}$ \\ ${ }^{1}$ Laboratoire de Mécanique Appliquée et Technologies Centre de Recherche en Sciences et Technologies Industrielles et de la Santé, \\ Mohammed V University in RABAT- ENSAM, Avenue de l'Armée Royale, BP 6207 Rabat, MOROCCO
}

Corresponding author:*mouhsin.nidal@gmail.com

\begin{abstract}
Solar desalination is becoming more reliable and common especially in developing countries where receive sufficient sunshine throughout the year. In addition, solar still devices are considered as one of the cheapest and simplest desalination methods depends on solar energy, but suffer from low productivity. This work presents an experimental analysis of the performance and productivity of novel cascade solar still with a modified absorber plate with additional baffles on the slope surfaces as a new attempt to enhance the productivity of solar stills. The solar intensity was taken as input and the productivity as output are considered for evaluating the solar still in order to examine the effect of the modified absorber plate on the performance and productivity of novel cascade solar still.
\end{abstract}

\section{Introduction}

Water is a gift from nature and is present in abundance. Over 70\% of the Earth's surface is covered by water but most of it is not suitable for direct human consumption. Over 97 percent of the earth's water is found in the oceans as salt water, and less than 3\% is freshwater [1]. Worldwide, 780 million people lack even basic drinking-water sources [2].

The availability of freshwater is shrinking day by day cause of the rapid industrial growth, growth of the population, water pollution, and bad water management [3]. Clearly, there is a worldwide potential need for applying conservative measures and effective management to save this valuable resource. Solar desalination is a process of purification methods that are used to get pure water from saline water. This kind of purification method is dependent on solar energy to power the process of purifying water.

Industrial desalination methods such as multiple effect desalination, multi-stage flash desalination, thermal vapor compression, mechanical vapor compression, are highly energy-consuming and required heat in the form of mechanical or electrical work. Undoubtedly, Solar desalination is the economical, and viable technique of purifying saline water [4], because of its simplicity and low manufacturing cost [5]. Solar stills are considered the traditional, the cheapest, and the cleanest method for converting brackish water to drinking water. However, in comparison with other conventional desalination methods, the efficiency and the production rate of the single basin solar still is very low. cascade solar still is one of the conventional solar still is used the step tray basin to increase the surface area of water in a small space to rise up evaporation, therefore, increase the production rate of distilled water. Several kinds of research were carried out in this technology for enhancing freshwater yield, shown that the important factor affecting the productivity is the depth of saline water in the solar still.

According to A. Safwat Nafey et.al [6], recently, cascade solar still has received much attention due to the higher productivity than the other basin types, because it offers a minimum depth of water. Kabeel et.al [7] investigated the performance of stepped solar still by studying the effect of depth and width. The maximum productivity of stepped solar still was obtained with a depth of $5 \mathrm{~mm}$ and width of $120 \mathrm{~mm}$, which lead to enhance productivity by $57.3 \%$ more than conventional solar still. Velmurugan et.al [8] fabricated and tested a stepped solar still with 50 trays, and added fins and pebbles to enhance the production rate by $98 \%$.

The productivity of the solar still can be improved by minimizing the depth of the water. This work presents, a novel cascade solar still with absorber plate used a several basins to separate the water area. Also improving the productivity by modified absorber plate. The new design of the absorber plate consists of an additional baffles fixed on the sloped surfaces.

In this current work, an experimental study of cascade solar still with additional baffles on slope surfaces of the absorber plate of novel cascade solar still. This new modification has been applicated in order to enhance the performance and the productivity of cascade solar still.

\footnotetext{
* Corresponding author: mouhsin.nidal@gmail.com
} 


\section{System description}

A Cascade solar still was designed and developed by Bouzaid et al. [9] and it was shown in figure 1. The powerful design of the new geometry provides a lot of advantages and higher productivity than the conventional solar stills.

The absorber plate of the cascade solar is made of a number of steps as the shape of the stairs. In comparison with the absorber plate and basin temperatures of the single basin still, the cascade solar still values still higher than the conventional stills. The main reasons for this difference:

-The trapped air in the stepped stills is heated rapidly more than the conventional still cause of the smaller air volume.

-The step-wise basin provides higher heat and mass transfer surface area more than the flat basin.

Therefore, leads to an increase in the water temperature of the basin water temperature of stepped solar still [11].

\section{still:}

Characteristics of the new design of cascade solar

- The glass cover inclined with an angle of $25^{\circ}$ to facilitate the runoff of condensed water to the collector.

- The basin is made of metal (aluminum); thermal insulation is achieved by a coating inside the basin.

- The absorber plate painted black and made of number of steps, with horizontal and inclined surfaces with the angle of $35^{\circ}$ for better orientation relative to the sun. The absorber plate inclination was equal to the latitude of Rabat (344ㄱ'N).

- The baffles added to the surface of absorption to minimize the flow velocity of the saline water and create new receiving solar surfaces to enhance the evaporation process of the still.

\section{Principal steps of solar still process:}

- The glass cover received the solar radiation

- the black surface absorbed the heat, then transferred to the saline water in the basin

- The water temperature increases, thus raises the rate of evaporation.

- The water vapor raised up and condenses on the inner surface of the glass cover.

The main advantages of the new design of the absorber plate:

- offering minimum depth of water.

- heating water quickly

- providing better orientation relative to the sun.

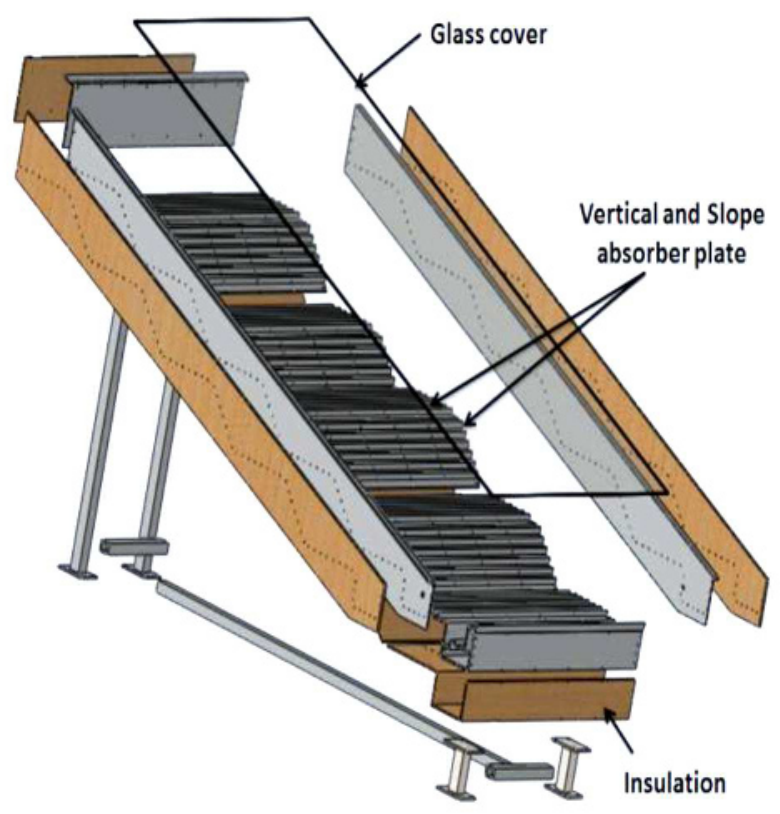

Fig. 1. Three-dimensional prototype drawing [10].

\section{Experimental procedure}

Experiments have performed at the Higher Normal School of Technical Education in Rabat-Morocco, on July 24th, 2019. Experiments started around 8:00 am to 6:00 pm. Different temperatures, solar insolation measured at every one hour of interval.

The experiments were conducted on August 8 and 9 for the modified absorber plate. The cascade solar still linked to a saline storage tank of 25 litters. For measuring the various temperatures was used thermocouples, three for the glass cover and six installed at the inner face of the absorber plate.

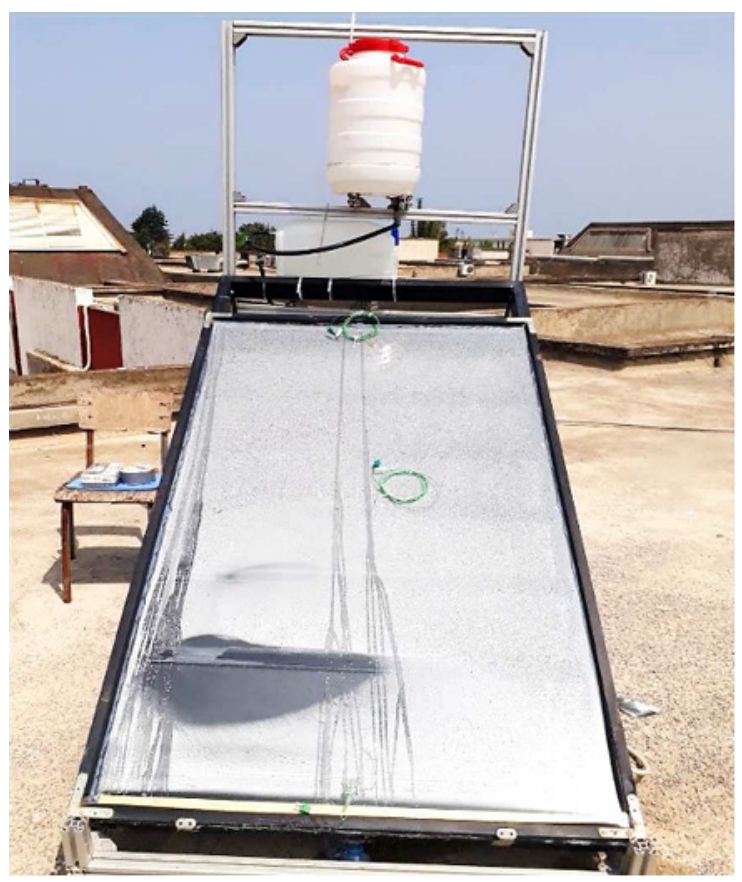

Fig. 2. Experimental set up of novel cascade solar still [9]. 


\section{Results and discussion}

The experimentations were conducted on two different days on cascade solar still with modified absorber plate. The results and discussion of the proposed work have been presented in the following sections.

As shown in Figure 4, it is noticed that the solar radiation intensity was initially low during the first hours, after that it gradually increases and achieves maximum intensity at mid-noon, then gradually decreases. For August 08 and 09, the solar radiation intensity recorded a maximum value of about $967 \mathrm{~W} / \mathrm{m}^{2}$ and $820 \mathrm{~W} / \mathrm{m}^{2}$, respectively at 13:00 hrs.

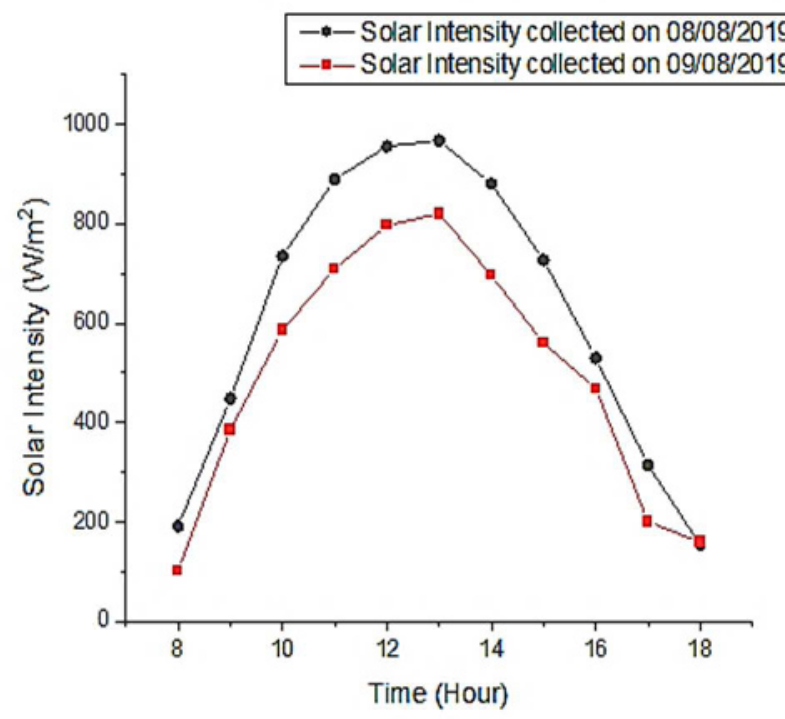

Fig.3. Hourly variation of solar radiation collected on 08 and 09 August 2019.

Figure 4 shows the hourly variation of experimental values of glass cover temperatures for the cascade solar still with modified absorber plate. The maximum temperature of the glass cover was reached at around 13:00 h. Maximum measured values for cascade solar still with baffles on slope surface of the absorber plate were $48{ }^{\circ} \mathrm{C}$, and $45^{\circ} \mathrm{C}$ respectively.

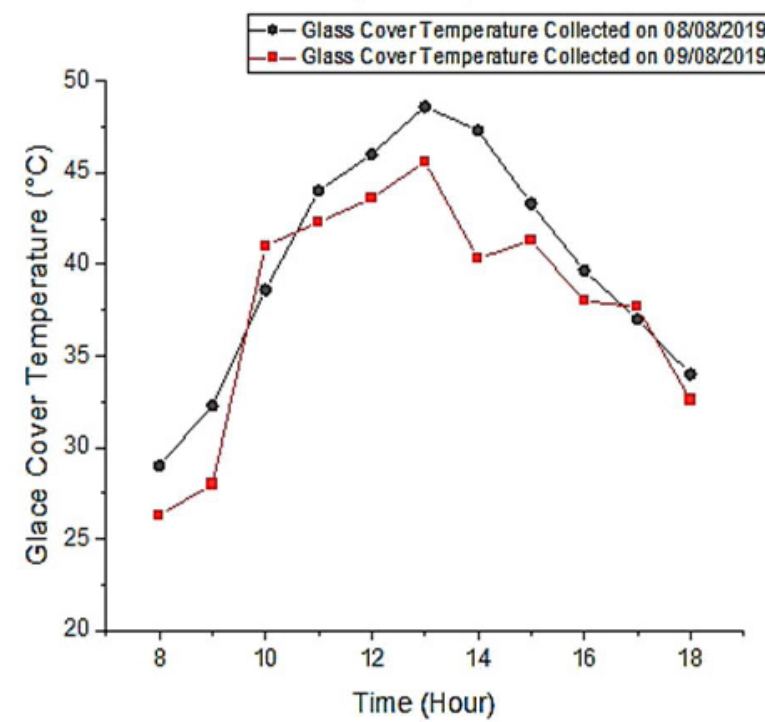

Fig.4. Hourly variations of glass cover temperature measured on the 08th and 09th of August 2019.
The figure 5 represents the hourly variation of modified absorber plate temperature and solar intensity of 08th and 09th August. It can clearly be seen from the illustrations that the variation of solar intensity has the similar behaviour of the absorber plate temperature. In addition, it can be observed that the absorber plate temperature increases with an increase of solar intensity, and the maximum of absorber plate temperature occurs at maximum of solar insulation. For August 08 and 09, the absorber plate temperature recorded a maximum value of about $66^{\circ} \mathrm{C}$ and $62^{\circ} \mathrm{C}$, respectively at 13:00 hr.

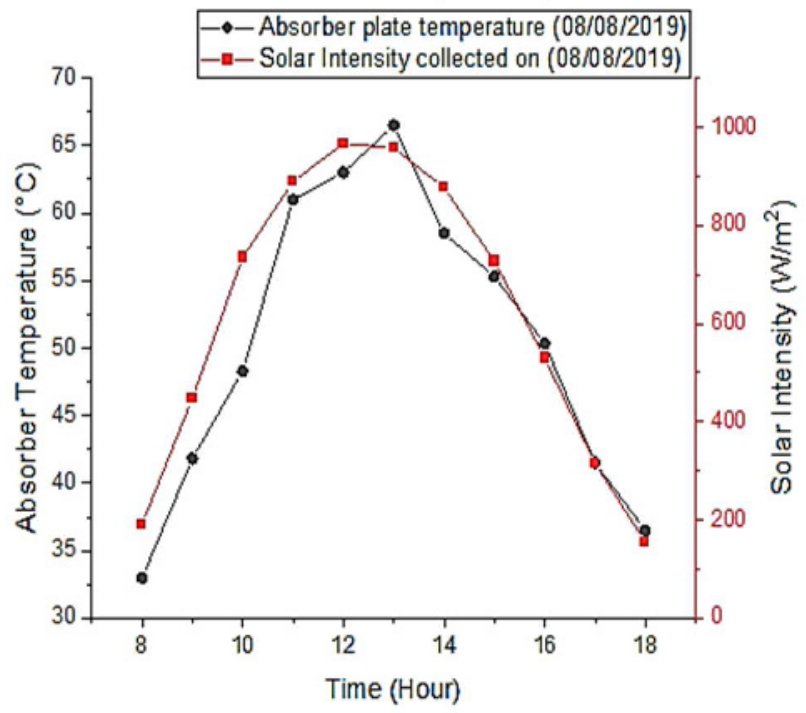

Fig.5. a. Hourly variations of the absorber plate temperature measured on the 08th of August 2019.

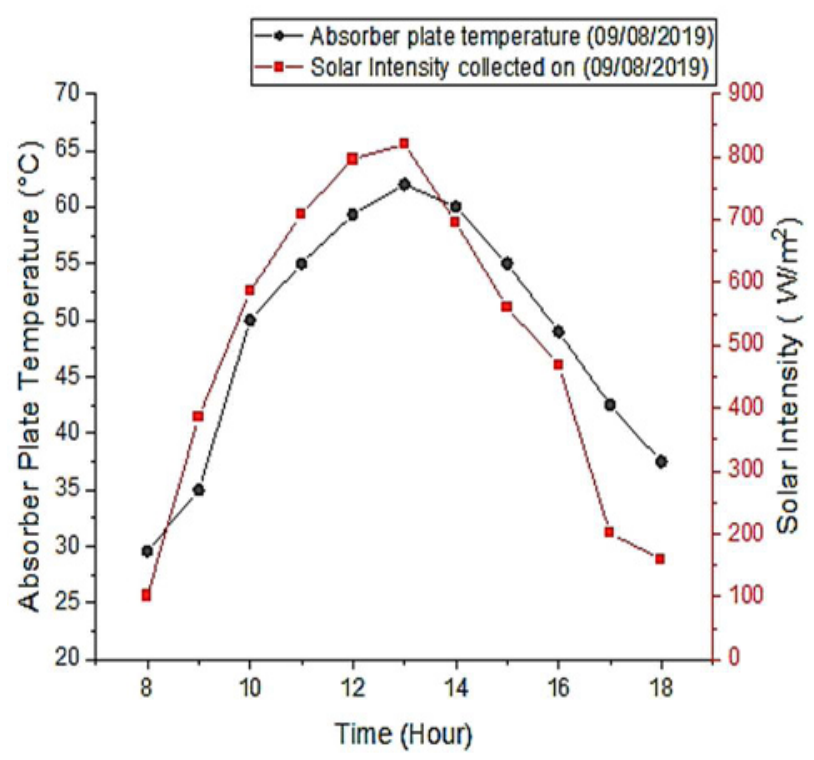

Fig.5. b. Hourly variations of the absorber plate temperature measured on the 09th of August 2019. 
Figure 6 shows the hourly variation of distillate output of the modified cascade solar still during the day (8 a.m. to 6 p.m.). It is observed that there was an increase in the water productivity during early hours of the day till reaches the maximum productivity around 13:00 $\mathrm{h}$. The maximum productivity values were obtained about $412 \mathrm{ml} / \mathrm{m}^{2} . \mathrm{hr}$ in the first day (08 August 2019) and $376 \mathrm{ml} / \mathrm{m}^{2} . \mathrm{hr}$ in the second day (09 August 2019).

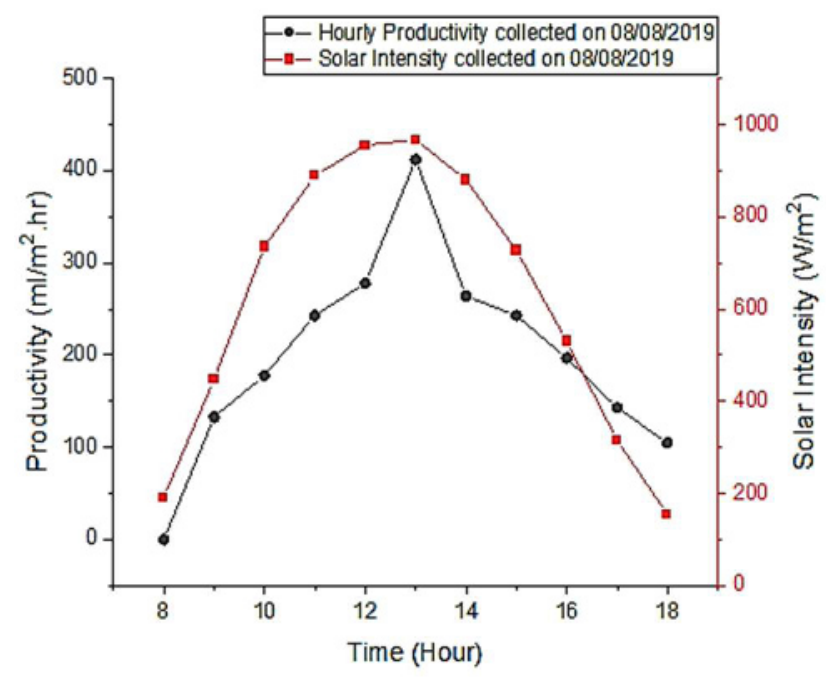

Fig.6. a. Hourly Productivity of the still collected on the 0 8th of August 2019.

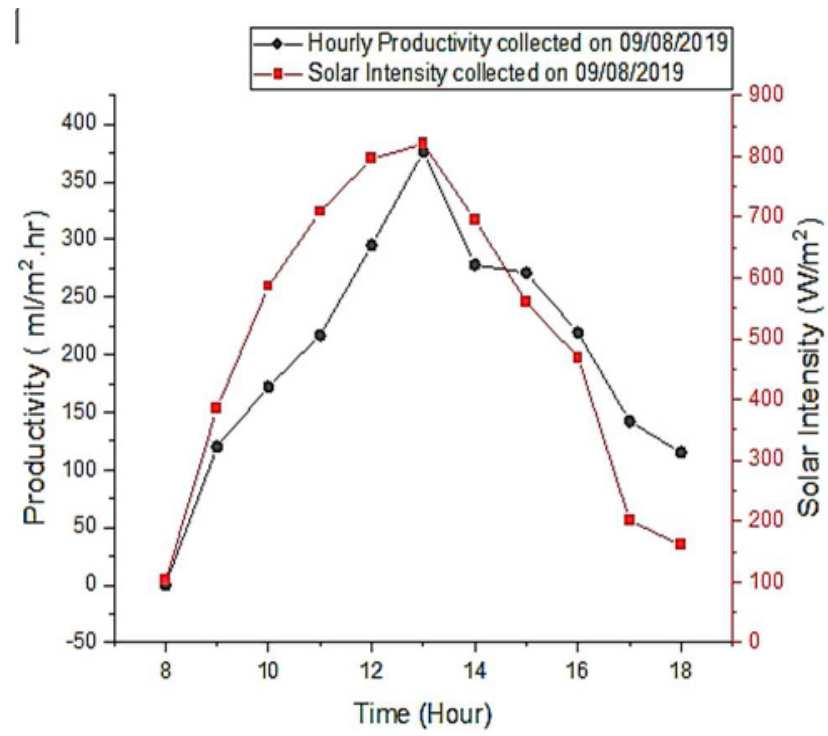

Fig.6. a. Hourly Productivity of the still collected on the 09th of August 2019.

From the experimentation results it can be clearly observed that the cascade solar still with additional baffles recorded important values and performance in comparison with the cascade solar still without baffles. An experimental analysis indicated that the hourly productivity of the cascade solar still with baffles can reach than $412 \mathrm{ml} / \mathrm{m}^{2} . \mathrm{hr}$ for $967 \mathrm{~W} / \mathrm{m}^{2}$ of solar intensity. While the productivity of pyramid single basin solar still [12] was around $350 \mathrm{ml} / \mathrm{m}^{2} . \mathrm{h}$ for $980 \mathrm{~W} / \mathrm{m}^{2}$ of solar intensity. Therefore, the novel cascade solar still design improves the productivity in comparison with other solar stills results.

\section{Conclusion}

In this study, a novel cascade solar still with baffles on the slope surface of the absorber plate, fabricated, and experimentally tested under real climatic conditions found in Rabat ( $\left.34^{\circ} 47^{\prime} \mathrm{N}\right)$, Morocco. The results indicate that the modified absorber plate improves the absorber plate temperature so the thermal performance of a modified cascade solar still can be considerably improved through the new modification. Based on the results of experiments conducted on cascade solar still with the modified absorber plate, the following conclusions can be drawn.

- It is observed that the absorber plate temperature on $8^{\text {th }}$ August is higher as compared with $9^{\text {th }}$ August. The experimental values of the maximum temperature of the absorber plate are $66^{\circ} \mathrm{C}$ and $62^{\circ} \mathrm{C}$ respectively around 13:00 h. The most likely reason for this difference is that the solar intensity in first day $(08 / 08 / 2019)$ higher than the second day $(09 / 08 / 2019)$. Moreover, the solar intensity is one of the main factors influencing on the performance of solar stills.

- The glass cover temperature of $8^{\text {th }}$ August is higher than on $9^{\text {th }}$ August, cause of the difference of the solar intensity amount. Maximum glass cover temperatures recorded are $48^{\circ} \mathrm{C}$, and $45^{\circ} \mathrm{C}$ respectively.

- The hourly distillate output of modified cascade solar still during daytime. The maximum values of productivity are obtained on $8^{\text {th }}$ and $9^{\text {th }}$ August 2019 are $412 \mathrm{ml} / \mathrm{m}^{2} . \mathrm{hr}$ and $378 \mathrm{ml} / \mathrm{m}^{2} . \mathrm{hr}$ respectively, at around of 1:00 p.m.

\section{References}

1. Shankar P. and Kumar S, "Solar Distillation-A Parametric Review."VSRD International Journal of Mechanical, Automobile and Production Engineering 2, (2012): 17-33.

2. Bhardwaj R., Ten Kortenaar M. V. and Mudde R. F., "Influence of condensation surface on solar distillation." Desalination 326 (2013): 37-45.

3. Kannan R., Selvaganesan C., Vignesh M., Babu B. R., Fuentes M., Vivar M., Skryabin I., and Srithar K. "Solar still with vapor adsorption basin: Performance analysis." Renewable Energy 62 (2014): 258-264.

4. Kalogirou, Soteris A. Solar energy engineering: processes and systems. Academic Press, 2013.

5. A.E. Kabeel, Z.M. Omara, M.M.Younes, 2015. Techniques used to improve the performance of the stepped solar still-A review. Renew Sustain. Energy Rev. vol.46, pp.178-188. 
6. A. SafwatNafeya, M. Abdelkaderb, A. Abdelmotalipb, and A.A. Mabrouka, _Parameters affectingsolar still productivityll, Energy Conversion \& Management, 41, 1797-1809, 2000.

7. Kabeel AE, Khalil A, Omara ZM, Younes MM. Theoretical and experimental parametric study of modified stepped solar still. Desalination. 2012; 289:12-20.

8. Velmurugan, Naveen Kumar, NoorulHaq and Srithar. "Performance analysis in stepped solar still for effluent desalination. " Energy 34 (2009): 11791186.

9. M. Bouzaid, O. Ansari, M. Taha-Janan, M. Oubrek. Experimental and Theoretical Analysis of a Novel Cascade Solar Desalination Still. FDMP, vol.14, no.3, pp.177-200, 2018

10. Nidal Mouhsin, Mariam Bouzaid, Mourad Taha-Janan, Mohamed Oubrek. Modeling and experimental study of cascade solar still. SN Applied Sciences. 2020; 2:708

11. Abdellah, S.; Badran, O.; Abu-Khader, M. M. (2008): Performance evaluation of a modified design of a single slope solar still. Desalination, vol. 219, no. 1-3, pp. 222-230.

12. Taamneh, Y. and M.M. Taamneh, 2012. Performance of pyramid-shaped solar still: Experimental study. Desalination, 291: 65-68. 